\title{
Complementary effects of organic and mineral fertilizers on maize production in the smallholder farms of Meru South District, Kenya
}

\author{
Edwin Mwiti Mutegi ${ }^{1}$, James Biu Kung' ${ }^{2}{ }^{2}$, Mucheru-Muna ${ }^{2}$, Pypers Pieter ${ }^{1}$, Daniel Njiru Mugendi ${ }^{2}$ \\ ${ }^{1}$ Tropical Soil Biology and Fertility (TSBF), Institute of CIAT, Nairobi, Kenya; \\ *Corresponding Author: emutegi@,cgiar.org \\ ${ }^{2}$ Department of Environmental Sciences, Kenyatta University, Nairobi, Kenya
}

Received 3 November 2011; revised 17 December 2011; accepted 15 January 2012

\section{ABSTRACT}

Low soil fertility is a major constraint to maize production in the small holder farms of Meru South District. This is mainly attributed to the mining of nutrients due to cropping without external addition of adequate nutrients. Mineral fertilizers are expensive hence un affordable by most small holder farmers. The use of organic matter to increase and maintain soil fertility is being considered as a solution to help the lowincome small holder farmers. A study was conducted in Mucwa location, Meru South District to determine the levels of complementarity between organic and mineral $\mathbf{N}$ amendments on maize yields and their influence on soil chemical properties. The experiment was set in a complete randomized block design (CRBD) with three replicates. The treatments were compared with the response obtained from control. The general soil fertility parameters changed slightly with Calcium, Magnesium and Potassium increasing in all treatments. The organic Carbon and total Nitrogen was higher in treatments that received sole organic $\mathbf{N}$ sources than in sole mineral $\mathbf{N}$ and a combination of organic and mineral $\mathrm{N}$ sources. The highest maize grain yield of 4.8 $\mathrm{t} \cdot \mathrm{ha}^{-1}$ and $4.2 \mathrm{t} \cdot \mathrm{ha}^{-1}$ were realized from sole application of calliandra during the 2005 Short rains and 2006 Long rains cropping seasons. Generally the maize grain yields were lower in treatments with mineral $\mathrm{N}$ alone compared to the treatments with organics. Treatments with sole calliandra and sole tithonia had the highest benefit cost ratio (BCR), followed closely by manure treatment. More so, integration of organic and mineral $N$ sources resulted to higher net benefit and BCR than the application of the recommended rate of mineral fertilizers. Results obtained indicated that the use of either organic or combined organic/mineral $\mathrm{N}$ soil amendment appear to be superior to using mineral amendment sources alone.

Keywords: Soil Fertility; Organic Carbon; Total Nitrogen; Benefit Cost Ratio

\section{INTRODUCTION}

Soil fertility depletion in the smallholder farms is the fundamental biophysical root cause for declining per capita food production in sub-Saharan Africa. The soils in the central highlands of Kenya are Humic Nitisols with moderate to high inherent fertility [1]. However, the area has suffered gross soil nutrient mining due to continuous cropping coupled with low levels of nutrient inputs and poor nutrient conservation practices. The situation is further accentuated by mounting population growth and land scarcity $[2,3]$. The results of this loss in soil productivity has been a continuous decline of maize yields in farmers' fields (to less than $2.0 \mathrm{t} \cdot \mathrm{ha}^{-1}$ ) whilst the maize cultivars grown have a potential of greater than $6.0 \mathrm{t} \cdot \mathrm{ha}^{-1}[4,5]$. The use of mineral fertilizers on staple food crops of maize (Zea mays L.) and beans (Phaseolus vulgaris L.) has generally been restricted to only a few farmers endowed with resources, such as cattle and land [6] and with high off-farm income [7]. The majority of the smallholder farmers, on the other hand have lacked the financial resources to purchase sufficient mineral fertilizers to replace the soil nutrients exported with harvested crop products. The situation is further aggravated by the fact that even the farmers using the inorganic inputs hardly use the recommended rates $\left(60 \mathrm{~kg} \cdot \mathrm{N} \cdot \mathrm{ha}^{-1}\right)$ with most of them applying less than $20 \mathrm{~kg} \cdot \mathrm{N} \cdot \mathrm{ha}^{-1}$ [8].

Organic inputs are often proposed as alternatives to mineral fertilizer. For instance, [9] reported that soil incorporation of calliandra and Leucaena green biomass with or without fertilizer increased soil nitrogen by $1 \%$ - 
$8 \%$ over a period of 4 years. During the same period, the total soil nitrogen declined by $2 \%-4 \%$ when biomass was not applied. [10] reported that combination of mineral fertilizers with organic nutrient sources can be considered as better options for increasing fertilizer use efficiency as a result of improved synchronization of nutriaent release and uptake by the crop [11]. A judicious combination of organic and mineral sources of nutrients may therefore be envisaged as it addresses both the problem of insufficient fertilizer supply and the large amounts of organic material required for nutrients supply.

A study was conducted in Mucwa sub location, Meru South District with the main objective of determining the levels of complementarities between organic and mineral $\mathrm{N}$ amendments on their influence on soil chemical properties and maize grain yields.

\section{MATERIALS AND METHOD}

\subsection{Site Description}

The study was conducted in Mucwa sub location, Chuka Division, in Meru South District. According to [1] the area is in upper midland 2 and 3 (UM2 and UM3) with an altitude of approximately $1373 \mathrm{~m}$ above sea level. This is a predominantly maize growing zone in the central highlands of Kenya. It experiences bimodal rains which range from 1200 to $1400 \mathrm{~mm}$ and mean temperature of about $200^{\circ} \mathrm{C}$ annually. The long rains (LR) are from March to June, and the short rains are from October to December. The predominant soil types are humic nitisols, commonly called the red Kikuyu loams. They are deep, well weathered, free draining with a friable clay texture and moderate to high inherent fertility [1].

\subsection{Experimental Treatments and Design}

The experiment was laid out as a randomized complete block design (RCBD) with 3 replicates. The plots were measuring $6 \times 4.5 \mathrm{~m}$ with $1 \mathrm{~m}$ and $1.5 \mathrm{~m}$ between and within plots respectively. The test crop was maize (Zea mays L., var. H513) planted at a spacing of 0.75 and $0.5 \mathrm{~m}$ inter- and intra-row, respectively. Three (3) seeds were sown per hole and thinned four weeks later to 2 plants. Nine external soil fertility amendment inputs were applied to give an equivalent amount of the recommended rate of nitrogen to meet maize nutrient requirements for an optimum crop production in the area (60 $\left.\mathrm{kg} \cdot \mathrm{N} \cdot \mathrm{ha}^{-1}\right)$.

The tenth treatment was absolute control (no soil fertility enhancement input) representing farmers on the lower end of resource endowment. The organic inputs (biomass transfer) were harvested, weighed, chopped and incorporated into the soil to a depth of $15 \mathrm{~cm}$ during land preparation. Calcium Ammonium Nitrate (CAN) was the source of mineral $\mathrm{N}$ and at all its application rates, one-third was applied 4 weeks after planting (WAP) and the other two-thirds was applied 8 WAP. To prevent phosphorous deficiencies confounding $\mathrm{N}$ response, all plots received $\mathrm{P}$ application at $60 \mathrm{~kg} \cdot \mathrm{P} \cdot \mathrm{ha}^{-1}$. The average nutrient composition of the organic inputs that were incorporated in the two seasons is shown in Table $\mathbf{1 .}$

\subsection{Sampling and Analysis}

Soil samples were collected from each plot at the beginning of the 2004 Short rains (SR) and the end of the experiment (2006 LR). The sampling depth will be 0 - 15 $\mathrm{cm}$. Six samplings were taken randomly in each plot using an alderman auger and then bulked to one sample to eliminate variability. A sub sample was taken for analysis of total $\mathrm{N}, \mathrm{C}$ and $\mathrm{pH}$ and exchangeable bases $(\mathrm{K}, \mathrm{Ca}$ and $\mathrm{Mg}$ ) using standard methods. At maturity, maize was harvested and the fresh weight of both grain and stover taken. The maize was then air-dried and the dry weight taken and expressed on a $12.5 \%$ water content basis. Treatment effects on maize yields and soil chemical properties were subjected to analysis of variance (ANOVA) using Genstat programme. Treatment means found to be significantly different from each other were separated by least significant differences (LSD) at $\mathrm{p}<0.05$.

\subsection{Economic Analysis}

The economic returns from the application of each treatment were calculated taking into account the total sales and total costs. The information used for benefitcost analysis was collected at the specific time of each activity in the course of each season. The benefit-cost

Table 1. Average nutrient composition (\%) of organic materials applied in the soil during the 2005 short and 2006 long rains at Mucwa, Meru South District, Kenya.

\begin{tabular}{|c|c|c|c|c|c|c|}
\hline Treatment & $\% \mathrm{~N}$ & $\% \mathbf{P}$ & $\% \mathrm{~K}$ & $\% \mathrm{Mg}$ & \% Ca & Ash \\
\hline Tithonia & 3.0 & 0.2 & 2.0 & 0.7 & 1.6 & 13.2 \\
\hline Manure & 1.0 & 0.3 & 0.9 & 0.4 & 1.4 & 46.1 \\
\hline Calliandra & 3.3 & 0.2 & 1.1 & 0.4 & 0.9 & 5.8 \\
\hline SED & 0.72 & 0.03 & 0.34 & 0.10 & 0.21 & 12.39 \\
\hline
\end{tabular}


analysis was done using farm gate prices of the various inputs, however, all the organic amendments (except manure) did not have market prices in the area and were therefore costed in terms of labour involved in harvesting and incorporation (Table 2).

Total cost included all the expenses for buying and applying the mineral fertilizers and the labor for collection, transporting and application of organic resources since they were collected near the experimental plots. The price of maize was taken to have a market value of USD $0.17 \mathrm{~kg}^{-1}$. Maize stover was used to feed cattle in the area (with a market value of USD 23 ton $^{-1}$ ). To test for significant probability differences of the various organic and mineral fertilizers, ANOVA was carried out. The total cost was subtracted from the total sales to get the net benefit for the specific season. The benefit cost ratio was calculated by dividing the net benefits with the total cost.

\section{RESULTS AND DISCUSSIONS}

\subsection{Maize Grain Yields}

One of the objectives of this study was to determine the effects of organic and mineral $\mathrm{N}$ sources on maize grain yields. Table 3 shows grain yields obtained during the two seasons (2005 SR and 2006 LR).

During the first season (2005 SR), sole calliandra treatment gave the highest maize grain yield of $4.8 \mathrm{t} \cdot \mathrm{ha}^{-1}$, followed by tithonia $+30 \mathrm{~kg} \cdot \mathrm{N} \cdot \mathrm{ha}^{-1}$ and $90 \mathrm{~kg} \cdot \mathrm{N} \cdot \mathrm{ha}^{-1}$ $\left(3.6 \mathrm{t} \cdot \mathrm{ha}^{-1}\right)$. The control gave the lowest maize grain yield across the treatments with $1.6 \mathrm{t} \cdot \mathrm{ha}^{-1}$ followed closely by fertilizer at $30 \mathrm{~kg} \cdot \mathrm{N} \cdot \mathrm{ha}^{-1}\left(1.8 \mathrm{t} \cdot \mathrm{ha}^{-1}\right)$. The yields obtained from fertilizer at $60 \mathrm{~kg} \cdot \mathrm{N} \cdot \mathrm{ha}^{-1}$ were not significantly different from the $90 \mathrm{~kg} \cdot \mathrm{N} \cdot \mathrm{ha}^{-1}\left(3.0 \mathrm{t} \cdot \mathrm{ha}^{-1}\right.$ and $3.6 \mathrm{t} \cdot \mathrm{ha}^{-1}$ respectively).

The results obtained during the 2006 LR season re-

Table 2. Parameters used to calculate the economic returns for the different nutrient replenishment technologies at Mucwa, Meru South District, Kenya.

\begin{tabular}{cc}
\hline Parameter & Actual values \\
\hline Price of TSP $(46 \% \mathrm{~N})$ & $0.61 \mathrm{USD} \cdot \mathrm{kg}^{-1}$ \\
Price of CAN $(26 \% \mathrm{~N})$ & $0.77 \mathrm{USD} \cdot \mathrm{kg}^{-1}$ \\
Labor cost & $0.13 \mathrm{USD} \cdot \mathrm{h}^{-1}$ \\
Labor cost for planting maize & $10.5 \mathrm{USD} \cdot \mathrm{ha}^{-1}$ \\
Labor for applying fertilizer & $0.74 \mathrm{USD} \cdot \mathrm{h}^{-1}$ \\
Labor for applying organic inputs & $2.9 \mathrm{USD} 100 \mathrm{~kg}^{-1}$ \\
Price of Maize & $0.17 \mathrm{USD} \cdot \mathrm{kg}^{-1}$ \\
Price of stover & $0.023 \mathrm{USD} \cdot \mathrm{kg}^{-1}$ \\
\hline
\end{tabular}

$\mathrm{DM}=$ Dry matter; Exchange rate $65 \mathrm{Ksh}=\mathrm{USD} 1$ (November, 2007).
Table 3. Maize grain yield $\left(\mathrm{t} \cdot \mathrm{ha}^{-1}\right)$ during the $2005 \mathrm{SR}$ and 2006 LR at Mucwa, Meru South District, Kenya.

\begin{tabular}{ccc}
\hline Treatment & 2005 SR & 2006 LR \\
\hline Calliandra & $4.8^{\mathrm{a}}$ & $4.2^{\mathrm{a}}$ \\
Tithonia & $3.1^{\mathrm{bcd}}$ & $3.4^{\mathrm{b}}$ \\
Manure & $3.5^{\mathrm{bc}}$ & $2.4^{\mathrm{d}}$ \\
Tithonia $+30 \mathrm{~kg} \cdot \mathrm{N} \cdot \mathrm{ha}^{-1}$ & $3.6^{\mathrm{b}}$ & $3.2^{\mathrm{bc}}$ \\
Calliandra $+30 \mathrm{~kg} \cdot \mathrm{N} \cdot \mathrm{ha}^{-1}$ & $2.9^{\mathrm{d}}$ & $2.5^{\mathrm{cd}}$ \\
Manure $+30 \mathrm{~kg} \cdot \mathrm{N} \cdot \mathrm{ha}^{-1}$ & $2.9^{\mathrm{d}}$ & $3.0^{\mathrm{b}}$ \\
Fertilizer $\left(90 \mathrm{~kg} \cdot \mathrm{N} \cdot \mathrm{ha}^{-1}\right)$ & $3.6^{\mathrm{b}}$ & $2.3^{\mathrm{c}}$ \\
Fertilizer $\left(60 \mathrm{~kg} \cdot \mathrm{N} \cdot \mathrm{ha}^{-1}\right)$ & $3.0^{\mathrm{bc}}$ & $2.0^{\mathrm{de}}$ \\
Fertilizer $\left.30 \mathrm{~kg} \cdot \mathrm{N} \cdot \mathrm{ha}^{-1}\right)$ & $1.8^{\mathrm{e}}$ & $0.4^{\mathrm{f}}$ \\
Control & $1.6^{\mathrm{e}}$ & $0.4^{\mathrm{f}}$ \\
\hline
\end{tabular}

Means with same letter in each column are not statistically different at $\mathrm{p}<$ 0.05 .

vealed that maize grain yield was between $0.4 \mathrm{t} \cdot \mathrm{ha}^{-1}$ and $4.2 \mathrm{t} \cdot \mathrm{ha}^{-1}$, which was against the expected grain yield of greater than $6 \mathrm{t} \cdot \mathrm{ha}^{-1}$ (Var. H 513) for the area. During this season, calliandra treatment gave the highest grain yield of $4.2 \mathrm{t} \cdot \mathrm{ha}^{-1}$, while the control and application of $30 \mathrm{~kg} \cdot \mathrm{N} \cdot \mathrm{ha}^{-1}$ gave the lowest maize grain yield $(0.4$ $\left.\mathrm{t} \cdot \mathrm{ha}^{-1}\right)$. Sole tithonia and tithonia $+30 \mathrm{~kg} \cdot \mathrm{N} \cdot \mathrm{ha}^{-1}$ gave signifi- cantly higher yields than all the other treatments (except in sole calliandra treatment). The yields obtained from application of $60 \mathrm{~kg} \cdot \mathrm{N} \cdot \mathrm{ha}^{-1}$ were not significantly differ- ent from those obtained in $90 \mathrm{~kg} \cdot \mathrm{N} \cdot \mathrm{ha}^{-1}$ treatment. Sole organics and integration of sole organics with 30 $\mathrm{kg} \cdot \mathrm{N} \cdot \mathrm{ha}^{-1}$ had higher yields than the recommended rate of mineral fertilizer $\left(60 \mathrm{~kg} \cdot \mathrm{N} \cdot \mathrm{ha}^{-1}\right)$. The application of organic alone or in combination with mineral fertilizers led to increased maize yield compared to the control.

The higher maize grain yields obtained during the $2005 \mathrm{SR}$ season from mineral fertilizer at $90 \mathrm{~kg} \cdot \mathrm{N} \cdot \mathrm{ha}^{-1}$ and $60 \mathrm{~kg} \cdot \mathrm{N} \cdot \mathrm{ha}^{-1}$ (though not significantly different from sole tithonia, sole manure and Tithonia $+30 \mathrm{~kg} \cdot \mathrm{N} \cdot \mathrm{ha}^{-1}$ ) could be attributed to nutrients being readily available from the mineral fertilizers as compared to nutrients from organic residues which must first undergo decomposition before they are available for crop uptake. The split application of mineral $\mathrm{N}$ could have also resulted to minimal leaching losses and better synchrony of nutrient availability to maize crop demand. [12] suggested that split $\mathrm{N}$ application should be implemented so as to increase plant $\mathrm{N}$ uptake and decrease potential for $\mathrm{N}$ losses. Another aspect that contributed to high maize yields during the 2005 SR season was the even distribution of rainfall throughout during the first three months of the cropping season. 
This promoted rapid growth since the soil moisture deficits were eliminated. The lower yield obtained from fertilizer at $30 \mathrm{~kg} \cdot \mathrm{N} \cdot \mathrm{ha}^{-1}$ in comparison to the 60 $\mathrm{kg} \cdot \mathrm{N} \cdot \mathrm{ha}^{-1}$ is probably because the $\mathrm{N}$ supplied was not enough to meet the maize crop demand since the recommended mineral $\mathrm{N}$ application rate for the area is 60 $\mathrm{kg} \cdot \mathrm{N} \cdot \mathrm{ha}^{-1}[13]$.

Lower moisture regimes characterized the 2006 long rains cropping season with $79 \%$ of the rainfall being received within the first 40 days of the season. This may in part have been responsible for the suppressed performance of maize crop during the 2006 LR period. The low moisture regimes in the soil could also have meant that most of the organic materials did not fully decompose in time, thus $\mathrm{N}$ was not fully released in time, and if it was, water was not available for the mineralized nutrients to be taken up by the crop. Soil moisture content influences $\mathrm{N}$ mineralization and availability and subsequent maize growth and uptake $[14,15]$ noted that variability in climatic factors such as rainfall and temperature make the synchrony between nutrient release from tree litter and crop uptake an elusive goal to achieve in practical terms. Insufficient moisture has also been reported to limit the response of crops to nutrients [16]. During this season, the better performance in sole tithonia and tithonia +30 $\mathrm{kg} \cdot \mathrm{N} \cdot \mathrm{ha}^{-1}$ is possibly due to high release of $\mathrm{N}$ through mineralization and this synchronized to plant uptake [17]. [18] noted that the overall secondary compounds (lignins and polyphenols) in tithonia are low compared with foliage of many trees. Tithonia contains $80 \%$ water that further contributes to rapid decomposition [19].

The relatively better performance from sole organics and integration of sole organics with $30 \mathrm{~kg} \cdot \mathrm{N} \cdot \mathrm{ha}^{-1}$ in comparison to sole mineral $\mathrm{N}$ sources could be due to provision of additional benefits (besides $\mathrm{N}$ ) by the organic inputs to the soil chemical and physical properties that in turn influence nutrient acquisition and plant growth [11]. Principal among these is the soil moisture holding capacity and provision of other macro-nutrients like calcium and magnesium [20,21]. Higher maize yields with organic and/or a combination of organics with mineral fertilizer has been reported elsewhere. For instance, research work by [22] and [23] have demonstrated that higher yields can be obtained when sole organics or their combinations with mineral fertilizer have been incorporated in comparison to sole mineral fertilizer treatment. $[24,25]$ reported that a combination of organic and mineral nutrient sources has been shown to result into synergy and improved synchronization of nutrient release and uptake by plants leading to higher yields. More so, addition of green manure and animal waste helps to reduce the total concentration of $\mathrm{Al}$ in the soils and thus reduce $\mathrm{Al}$ phototoxicity and increase crop growth [26,27]. Another likely cause for the observed higher yields in the organic and/or mixed treatments was reduced water stress compared with sole mineral fertilizer treatments due to the presence of organic materials. The organic residues improve water holding capacity and moisture retention.

\subsection{Soil Chemical Characteristics}

The second objective of the study was to determine the influence of the various organic and mineral $\mathrm{N}$ resources on soil chemical properties. The general soil fertility parameters changed with the application of the various organic and mineral $\mathrm{N}$ sources as shown in Tables $\mathbf{4}$ and $\mathbf{5}$.

Table 4. Soil chemical properties $(0-15 \mathrm{~cm})$ at the beginning of the experiment (2004 SR) in Mucwa, Meru South District, Kenya.

\begin{tabular}{|c|c|c|c|c|c|c|}
\hline \multirow{2}{*}{ Treatment } & $\mathrm{pH}$ & $\mathrm{Ca}$ & $\mathrm{Mg}$ & K & \multirow{2}{*}{$\mathrm{C} \%$} & \multirow{2}{*}{ N\% } \\
\hline & $\left(\mathrm{H}_{2} \mathrm{O}\right)$ & \multicolumn{3}{|c|}{ Exchangeable (cmol/kg) } & & \\
\hline Manure & $4.9^{\mathrm{cd}}$ & $0.9^{\mathrm{e}}$ & $0.18^{\mathrm{a}}$ & $0.3^{\mathrm{c}}$ & $1.9^{\mathrm{d}}$ & $0.23^{\mathrm{c}}$ \\
\hline Manure $+30 \mathrm{~kg} \cdot \mathrm{N} \cdot \mathrm{ha}^{-1}$ & $5.2^{\mathrm{a}}$ & $1.5 \mathrm{a}$ & $0.18^{\mathrm{a}}$ & $0.4^{\mathrm{b}}$ & $2.2^{\mathrm{ab}}$ & $0.25^{\mathrm{ab}}$ \\
\hline Tithonia & $5.1^{\mathrm{ab}}$ & $1.2 \mathrm{~b}^{\mathrm{c}}$ & $0.22^{\mathrm{a}}$ & $0.5^{\mathrm{a}}$ & $2.3^{\mathrm{a}}$ & $0.25^{\mathrm{ab}}$ \\
\hline Calliandra & $5.0^{\mathrm{bc}}$ & $1.1^{\mathrm{cd}}$ & $0.18^{\mathrm{a}}$ & $0.4^{\mathrm{b}}$ & $1.9^{\mathrm{d}}$ & $0.24^{\mathrm{bc}}$ \\
\hline Tithonia $+30 \mathrm{~kg} \cdot \mathrm{N} \cdot \mathrm{ha}^{-1}$ & $4.8^{\mathrm{d}}$ & $1.0^{\mathrm{de}}$ & $0.20^{\mathrm{a}}$ & $0.3^{\mathrm{c}}$ & $2.0^{\mathrm{cd}}$ & $0.26^{\mathrm{a}}$ \\
\hline Calliandra $+30 \mathrm{~kg} \cdot \mathrm{N} \cdot \mathrm{ha}^{-1}$ & $5.0^{\mathrm{bc}}$ & $1.0^{\mathrm{de}}$ & $0.17^{\mathrm{a}}$ & $0.3^{\mathrm{c}}$ & $2.0^{\text {cd }}$ & $0.23^{\mathrm{c}}$ \\
\hline Fertilizer $\left(30 \mathrm{~kg} \cdot \mathrm{N} \cdot \mathrm{ha}^{-1}\right)$ & $4.9^{\text {cd }}$ & $1.0^{\mathrm{de}}$ & $0.19^{\mathrm{a}}$ & $0.3^{\mathrm{c}}$ & $2.1^{\mathrm{bc}}$ & $0.24^{\mathrm{bc}}$ \\
\hline Fertilizer $\left(60 \mathrm{~kg} \cdot \mathrm{N} \cdot \mathrm{ha}^{-1}\right)$ & $5.1^{\mathrm{ab}}$ & $1.3^{\mathrm{b}}$ & $0.23^{\mathrm{a}}$ & $0.3^{\mathrm{c}}$ & $2.1^{\mathrm{bc}}$ & $0.24^{\mathrm{bc}}$ \\
\hline Fertilizer $\left(90 \mathrm{~kg} \cdot \mathrm{N} \cdot \mathrm{ha}^{-1}\right)$ & $4.9^{\mathrm{cd}}$ & $1.0^{\mathrm{de}}$ & $0.18^{\mathrm{a}}$ & $0.3^{\mathrm{c}}$ & $2.0^{\mathrm{cd}}$ & $0.25^{\mathrm{ab}}$ \\
\hline Control & $4.8^{\mathrm{d}}$ & $1.0^{\mathrm{de}}$ & $0.20^{\mathrm{a}}$ & $0.4^{\mathrm{b}}$ & $1.9^{\mathrm{d}}$ & $0.24^{\mathrm{bc}}$ \\
\hline
\end{tabular}

Means with same letter in each column are not statistically different at $\mathrm{p}<0.05$. 
Table 5. Soil chemical properties $(0-15 \mathrm{~cm})$ at the end of 2006 Long rain season at the experimental site, Mucwa, Meru South District, Kenya.

\begin{tabular}{|c|c|c|c|c|c|c|}
\hline \multirow{2}{*}{ Treatment } & $\mathrm{pH}$ & $\mathrm{Ca}$ & $\mathrm{Mg}$ & $\mathrm{K}$ & \multirow{2}{*}{$\mathrm{C} \%$} & \multirow{2}{*}{ N\% } \\
\hline & $\left(\mathrm{H}_{2} \mathrm{O}\right)$ & \multicolumn{3}{|c|}{ Exchangeable $(\mathrm{cmol} / \mathrm{kg})$} & & \\
\hline Manure & $5.6^{\mathrm{a}}$ & $2.9^{\mathrm{b}}$ & $1.5^{\mathrm{a}}$ & $1.5^{\mathrm{a}}$ & $1.7^{\mathrm{bc}}$ & $0.28^{\mathrm{a}}$ \\
\hline Manure $+30 \mathrm{~kg} \cdot \mathrm{N} \cdot \mathrm{ha}^{-1}$ & $5.2^{\mathrm{b}}$ & $3.4^{\mathrm{a}}$ & $1.1^{\mathrm{b}}$ & $1.3^{\mathrm{a}}$ & $2.2^{\mathrm{ab}}$ & $0.28^{\mathrm{a}}$ \\
\hline Tithonia & $5.1^{\mathrm{bc}}$ & $2.3^{\mathrm{c}}$ & $0.8^{\mathrm{cd}}$ & $1.3^{\mathrm{a}}$ & $1.4^{\mathrm{c}}$ & $0.28^{\mathrm{a}}$ \\
\hline Calliandra & $4.9^{\mathrm{de}}$ & $1.9^{\mathrm{d}}$ & $0.7^{\mathrm{d}}$ & $0.5^{\mathrm{bc}}$ & $2.5^{\mathrm{a}}$ & $0.27^{\mathrm{ab}}$ \\
\hline Tithonia $+30 \mathrm{~kg} \cdot \mathrm{N} \cdot \mathrm{ha}^{-1}$ & $5.1^{\mathrm{bc}}$ & $1.3^{\mathrm{e}}$ & $0.6^{\mathrm{d}}$ & $0.3^{\mathrm{c}}$ & $2.0^{\mathrm{ab}}$ & $0.22^{\mathrm{d}}$ \\
\hline Calliandra $+30 \mathrm{~kg} \cdot \mathrm{N} \cdot \mathrm{ha}^{-1}$ & $4.8^{\mathrm{e}}$ & $1.9^{\mathrm{d}}$ & $1.0^{\mathrm{bc}}$ & $0.4^{\mathrm{c}}$ & $1.5^{\mathrm{bc}}$ & $0.18^{\mathrm{e}}$ \\
\hline $30 \mathrm{~kg} \cdot \mathrm{N} \cdot \mathrm{ha}^{-1}$ & $5.1^{\mathrm{bc}}$ & $2.0^{\mathrm{d}}$ & $1.0^{\mathrm{bc}}$ & $0.5^{\mathrm{bc}}$ & $1.7^{\mathrm{bc}}$ & $0.22^{\mathrm{d}}$ \\
\hline $60 \mathrm{~kg} \cdot \mathrm{N} \cdot \mathrm{ha}^{-1}$ & $4.9^{\mathrm{de}}$ & $2.2^{\text {cd }}$ & $0.7^{\mathrm{d}}$ & $0.5^{\mathrm{bc}}$ & $2.0^{\mathrm{ab}}$ & $0.26^{\mathrm{bc}}$ \\
\hline $90 \mathrm{~kg} \cdot \mathrm{N} \cdot \mathrm{ha}^{-1}$ & $5.0^{\text {cd }}$ & $1.9^{\mathrm{d}}$ & $0.6^{\mathrm{d}}$ & $0.4^{\mathrm{c}}$ & $1.2^{\mathrm{cd}}$ & $0.26^{\mathrm{bc}}$ \\
\hline Control & $4.8^{\mathrm{e}}$ & $1.9^{\mathrm{d}}$ & $0.7^{\mathrm{e}}$ & $0.5^{\mathrm{bc}}$ & $1.6^{\mathrm{bc}}$ & $0.25^{\mathrm{c}}$ \\
\hline
\end{tabular}

Means with same letter in each column are not statistically different at $\mathrm{p}<0.05$.

The soil $\mathrm{pH}$ increased significantly in sole manure treatment $(\mathrm{p}<0.05)$ while it declined (though not significantly) in treatments that received fertilizer at 60 $\mathrm{kg} \cdot \mathrm{N} \cdot \mathrm{ha}^{-1}$ and calliandra combined with half recommended rate of fertilizer at the end of the study period. However, the $\mathrm{pH}$ remained constant in manure +30 $\mathrm{kg} \cdot \mathrm{N} \cdot \mathrm{ha}^{-1}$, sole tithonia and the control treatments.

The $\mathrm{pH}$ of the soils ranged from 4.8 to 5.6 indicating that these soils were acidic. Under such conditions, the availability of the base forming cations is limited since the soil solution is mostly occupied by aluminium and hydrogen ions. The increment of soil $\mathrm{pH}$ with additions of manure could be attributed to the reduction of exchangeable aluminium in the acidic soils. This reduction is considered to occur through aluminium precipitation or chelation of organic colloids [27]. Increased $\mathrm{pH}$ with manure additions could also be attributed to increased levels of exchangeable bases ( $\mathrm{K}, \mathrm{Mg}$ and $\mathrm{Ca}$ ). The significant increase in $\mathrm{pH}$ with manure application corresponds with the findings by [28] and [29]. Increasing the $\mathrm{pH}$ of acidic soils improves plant-availability of macronutrients while reducing the solubility of elements such as $\mathrm{Al}$ and $\mathrm{Mn}[23,30]$. The magnitude of the rise in soil $\mathrm{pH}$ varies depending on the type of manure, its rate of application and the buffering capacity of the soil [31]. [32] noted that manures have the advantage of supplying essential plant elements either directly or indirectly by alleviating aluminium toxicity or producing organic acids thereby increasing nutrient availability.

Exchangeable $\mathrm{Ca}$ increased significantly $(\mathrm{p}<0.05)$ in all treatments with sole manure, manure $+30 \mathrm{~kg} \cdot \mathrm{N} \cdot \mathrm{ha}^{-1}$, sole calliandra and calliandra $+30 \mathrm{~kg} \cdot \mathrm{N} \cdot \mathrm{ha}^{-1}$ treatments having the highest increase in Ca content. Exchangeable
$\mathrm{Mg}$ also increased significantly in all treatments with sole manure having the highest $\mathrm{Mg}$ increment. Exchangeable potassium also increased significantly $(p<0.05)$ in sole manure, manure $+30 \mathrm{~kg} \cdot \mathrm{N} \cdot \mathrm{ha}^{-1}$ and sole tithonia treatments. The observed increase in exchangeable cations is consistent with the work of $[33,34]$ who reported an increase in exchangeable $\mathrm{K}$ and $\mathrm{Ca}$ after application of organic inputs. These are highly leached soils [1] and in such soils the order of adsorption of bases is $\mathrm{Ca}>\mathrm{Mg}>$ $\mathrm{K}$. Thus, continued leaching more of potassium followed by magnesium ions leaving relatively more calcium still adsorbed. In general, these soils were moderately acidic with medium to low nutrient stocks of exchangeable bases with a consequent effect on the availability of macro plant nutrients. This is partly because of the decomposition of organic materials yielding acids with release of hydrogen ions and also the reduced levels of bases due to leaching. Similar observations were made by [13] in some humic Nitisols in Kandara (Murang'a District, Kenya).

Organic carbon declined in all treatments except in sole calliandra treatment where it increased significantly by the end of the study period. The decreased $\mathrm{C}$ levels could be associated with the rapid decomposition rates in the study area and the fact that the organic input (tithonia) was of high quality. The $\mathrm{N}$ content in the organic materials also influence decomposition and $\mathrm{N}$ release. [11] noted that the $\mathrm{N}$ concentration in tithonia is higher than the critical levels of $2.0 \%$ and $2.5 \%$ below which net immobilization of $\mathrm{N}$ would be expected. However, increase in $\mathrm{C}$ levels in sole calliandra treatment could be attributed to lower rates of decomposition and mineralization of the biomass as a result of high polyphenol 
contents which bind with $\mathrm{N}$ and hence lower its decomposition rate and $\mathrm{N}$ release $[35,36]$. On average, the organic carbon was higher in soils receiving organic amendments or a combination of mineral fertilizers with organic amendments compared to soils receiving mineral fertilizers alone by the end of 2006 LR cropping season. This was because whereas the organic material had a major impact on mineralization rate by increasing soil $\mathrm{C}$ directly, the effect of mineral $\mathrm{N}$ fertilizer was less pronounced since it increased $\mathrm{C}$ only indirectly by improving plant growth [37]. These results corroborates with those of [35] who reported that the use of organic amendments either singly or in combination with mineral fertilizers play a vital role in sequestering $\mathrm{C}$ and building up soil fertility.

Total $\mathrm{N}$ increased in all treatments except in tithonia + $30 \mathrm{~kg} \cdot \mathrm{N} \cdot \mathrm{ha}^{-1}$, calliandra $+30 \mathrm{~kg} \cdot \mathrm{N}^{-1}$ and mineral fertilizer $\left(90 \mathrm{~kg} \cdot \mathrm{N} \cdot \mathrm{ha}^{-1}\right)$ which recorded an insignificant decrease. On average, treatments that received sole organic $\mathrm{N}$ amendments were higher in total $\mathrm{N}$ than the treatments that received integrations (of organic and mineral fertilizers) and sole application of mineral $\mathrm{N}$ fertilizers. The relative increase of total $\mathrm{N}$ at the end of the experiment could be attributed to minimal uptake of total $\mathrm{N}$ due to poorly distributed rainfall in 2006 LR season (Data not shown). The poor distribution of rainfall resulted to reduced nutrient availability to the maize crop. [35] noted that even distribution of rainfall and availability of sufficient amounts of rainfall are very important factors to crop production without which crop yields decline or even fail. However, total $\mathrm{N}$ was highest in all treatments that received organic residues in comparison to sole mineral $\mathrm{N}$ treatments. This could be attributed to the fact that the organics must first of all undergo microbial decomposition unlike the mineral $\mathrm{N}$ fertilizers which are applied in plant available form with subsequent losses through leaching and denitrification very early in the season.

\subsection{Cost-Benefit Analysis}

An economic analysis was done on the different organic and mineral $\mathrm{N}$ inputs during the 2005 SR and 2006 LR season. The organic amendments (except manure) did not have market prices in the area and were thus costed in terms of labour involved in harvesting and incorporation. The results are presented in Table 6.

Cost-benefit analysis (CBA) during the 2005 SR season indicated sole calliandra treatment gave the highest net benefit of USD 1089 and was followed by tithonia + $30 \mathrm{~kg} \cdot \mathrm{N} \cdot \mathrm{ha}^{-1}$ (USD 844) which was not significantly different $(\mathrm{p}<0.05)$ from sole manure and sole tithonia treatment (USD 800 and USD 621 respectively). The lowest net benefit was recorded in control treatment (USD 376) and was followed by $30 \mathrm{~kg} \cdot \mathrm{N} \cdot \mathrm{ha}^{-1}$ treatment with USD 488 . The net benefits observed in $60 \mathrm{~kg} \cdot \mathrm{N} \cdot \mathrm{ha}^{-1}$ and $90 \mathrm{~kg} \cdot \mathrm{N} \cdot \mathrm{ha}^{-1}$ were not significantly different from each other (707 and USD 733 respectively). This indicates that the additional mineral $\mathrm{N}$ in the $90 \mathrm{~kg} \cdot \mathrm{ha}^{-1}$ treatment did not offer an economic benefit since the observed maize grain yield in the $60 \mathrm{~kg} \cdot \mathrm{ha}^{-1}$ and $90 \mathrm{~kg} \cdot \mathrm{ha}^{-1}$ treatment (Table 6) was also not significantly different.

For the same period (2005 SR) sole calliandra yielded the highest benefit-cost ratio (BCR) of USD 12.4 and

Table 6. Cost-benefit ratios for different soil fertility amendments on maize yields during the 2005 SR and 2006 LR at Mucwa, Kenya.

\begin{tabular}{|c|c|c|c|c|c|c|c|c|}
\hline \multirow{2}{*}{ Trt } & \multicolumn{2}{|c|}{ Total sales (USD)) } & \multicolumn{2}{|c|}{ Total cost (USD) } & \multicolumn{2}{|c|}{ Net benefit (USD) } & \multicolumn{2}{|c|}{ Benefit-Cost ratio } \\
\hline & SR 05 & LR 06 & SR 05 & LR 06 & SR 05 & LR 06 & SR 05 & LR 06 \\
\hline 1 & $1176^{\mathrm{a}}$ & $3342^{\mathrm{a}}$ & $88^{\mathrm{cd}}$ & $83^{\mathrm{cd}}$ & $1089^{\mathrm{a}}$ & $991^{\mathrm{a}}$ & $12.4^{\mathrm{a}}$ & $11.9^{\mathrm{a}}$ \\
\hline 2 & $864^{\mathrm{bc}}$ & $2751^{\mathrm{b}}$ & $78^{\mathrm{de}}$ & $80^{\mathrm{cd}}$ & $786^{\text {bcd }}$ & $834^{\mathrm{ab}}$ & $10.1^{\mathrm{b}}$ & $10.4^{\mathrm{a}}$ \\
\hline 3 & $884^{\mathrm{bc}}$ & $1993^{d}$ & $85^{\mathrm{cd}}$ & $76^{\mathrm{d}}$ & $799^{\mathrm{bc}}$ & $621^{\mathrm{cd}}$ & $9.4^{\mathrm{bc}}$ & $8.1^{\mathrm{bc}}$ \\
\hline 4 & $949^{\mathrm{b}}$ & $2609^{\mathrm{bc}}$ & $105^{\mathrm{bc}}$ & $102^{\mathrm{bc}}$ & $844^{\mathrm{b}}$ & $779^{\mathrm{bc}}$ & $8.0^{\mathrm{cd}}$ & $7.6^{\mathrm{c}}$ \\
\hline 5 & $764^{\mathrm{c}}$ & $2046^{\mathrm{cd}}$ & $95^{\mathrm{cd}}$ & $92^{\mathrm{bcd}}$ & $670^{\text {cd }}$ & $605^{\mathrm{d}}$ & $7.1^{\text {def }}$ & $6.6^{\mathrm{cd}}$ \\
\hline 6 & $765^{\mathrm{c}}$ & $1195^{\mathrm{e}}$ & $98^{\mathrm{cd}}$ & $86^{\mathrm{cd}}$ & $667^{\mathrm{d}}$ & $407^{\mathrm{e}}$ & $6.8^{\mathrm{def}}$ & $4.7^{\mathrm{def}}$ \\
\hline 7 & $922^{\mathrm{b}}$ & $1943^{d}$ & $189^{\mathrm{a}}$ & $179^{\mathrm{a}}$ & $733^{\text {bcd }}$ & $522^{\mathrm{d}}$ & $3.9^{\mathrm{g}}$ & $2.9^{\mathrm{f}}$ \\
\hline 8 & $824^{\mathrm{bc}}$ & $1734^{d}$ & $117^{\mathrm{b}}$ & $109^{\mathrm{b}}$ & $707^{\mathrm{cd}}$ & $544^{\mathrm{d}}$ & $6.0^{\mathrm{f}}$ & $5.0^{\mathrm{de}}$ \\
\hline 9 & $573^{\mathrm{d}}$ & $551^{\mathrm{f}}$ & $84^{\mathrm{cd}}$ & $74^{\mathrm{d}}$ & $488^{\mathrm{e}}$ & $261^{\mathrm{f}}$ & $5.8^{\mathrm{f}}$ & $3.5^{\mathrm{ef}}$ \\
\hline 10 & $436^{\mathrm{e}}$ & $448^{\mathrm{f}}$ & $60^{\mathrm{e}}$ & $50^{\mathrm{e}}$ & $377^{\mathrm{e}}$ & $182^{\mathrm{f}}$ & $6.3^{\mathrm{ef}}$ & $3.6^{\mathrm{ef}}$ \\
\hline
\end{tabular}

Treatment $\left(1=\right.$ Calliandra; $2=$ Tithonia; $3=$ Manure; $4=$ Tithonia $+30 \mathrm{~kg} \cdot \mathrm{N} \cdot \mathrm{ha}^{-1} ; 5=$ Calliandra $+30 \mathrm{~kg} \cdot \mathrm{N} \cdot \mathrm{ha}^{-1} ; 6=\mathrm{Manure}+30 \mathrm{~kg} \cdot \mathrm{N} \cdot \mathrm{ha}{ }^{-1} ; 7=90$ $\mathrm{kg} \cdot \mathrm{N} \cdot \mathrm{ha}^{-1} ; 8=60 \mathrm{~kg} \cdot \mathrm{N} \cdot \mathrm{ha}^{-1} ; 9=30 \mathrm{~kg} \cdot \mathrm{N} \cdot \mathrm{ha}^{-1} ; 10=$ Control. 
was followed by sole tithonia (USD 10.1) and sole manure treatment (USD 9.4). The control treatment had significantly higher BCR than $90 \mathrm{~kg} \cdot \mathrm{N} \cdot \mathrm{ha}^{-1}$ (USD 6.3 compared to USD 3.9 respectively). Treatments involving sole organics and/or their integrations with mineral $\mathrm{N}$ sources recorded a higher BCR during this season.

During the 2006 LR season, a similar trend was observed with sole calliandra giving the highest net benefit of USD 991 while the control and $30 \mathrm{~kg} \cdot \mathrm{N} \cdot \mathrm{ha}^{-1}$ recorded the lowest (USD 182 and USD 261 respectively). The observed BCR was also in the order of sole organic treatments $>$ organics + mineral $\mathrm{N}$ treatments $>$ sole mineral $\mathrm{N}$ treatments.

On average, integrations of organics and mineral fertilizers had a higher net benefit and BCR than sole application of mineral fertilizers. This indicates that sole organics or their integrations with mineral fertilizers is a more economically profitable investment amongst the small holder farmers in Meru South District.

Studies indicate that combination of organic and mineral nutrient sources ensure greater synchrony between nutrients released and plant uptake and hence improved crop yields [37]. This explains the observation that, on average, integrations of organic $\mathrm{N}$ inputs with mineral fertilizers gave higher net benefits than the recommended rate of fertilizer $\left(60 \mathrm{~kg} \cdot \mathrm{N} \cdot \mathrm{ha}^{-1}\right)$. Considering that farmers may not be able to afford the high cost of purchasing mineral fertilizers, the use of organic inputs or their integrations with mineral fertilizers may form a major supplement or complement to replenishing nutrient deficiencies and ensuring high crop yields.

The integration of mineral fertilizers with organic inputs or sole application of organic inputs has been regarded as a more profitable alternative in low input systems, countering the large cost of fertilizers [23]. This study confirmed that sole application of organic and/or their integrations with mineral fertilizers can be an alternative to the limited use of fertilizers.

However, this strategy may be limited by the high proportions of organic inputs required, labour required for cutting, carrying and incorporating in sole application of organics [37]. Farmers are therefore encouraged to establish their own "biomass banks" within their farms so as to reduce the transport cost and labour cost that may be incurred in search for the biomass.

\section{CONCLUSION AND RECOMMENDATIONS}

The results presented herein show that the application of organic and mineral $\mathrm{N}$ sources improved the general soil fertility parameters with $\mathrm{Ca}, \mathrm{Mg}$ and $\mathrm{K}$ increasing in all treatments. Organics and/or mineral $\mathrm{N}$ soil amendments produce better maize yields to those obtained where the recommended mineral $\mathrm{N}$ sources are used alone. However, the organic materials may not be available in large amounts that are required for sole application. The third objective of this study was to evaluate the economic profitability of the various soil nutrient replenishment inputs. Treatments with sole calliandra and sole tithonia had the highest BCR, followed closely by manure treatment. More so, integration of organic and mineral $\mathrm{N}$ sources resulted to higher net benefit and BCR than the application of the recommended rate of mineral fertilizers. Farmers are therefore are encouraged to adopt the combination of organic and mineral fertilizers as they resulted in high maize grain yields and improved soil chemical properties.

\section{ACKNOWLEDGEMENTS}

The authors are grateful and greatly indebted to RUFORUM for providing financial support for the field experimentation and soil analysis. The assistance in the soil and plants analysis by the KARI- Muguga laboratory staff is highly acknowledged.

\section{REFERENCES}

[1] Jaetzold, R., Schimdt, H., Hornetz, B. and Shisanya, C. (2006) Farm management handbook of Kenya. Natural conditions and farm information Vol II/C. East Kenya. Ministry of Agriculture, Nairobi.

[2] Smaling, E. (1993) Soil nutrient depletion in sub-Saharan Africa. In: Van Reuler, H. and Prins, W., Eds., The Role of Plant Nutrients for Sustainable Food Crop Production in Sub-Saharan Africa, VKP, Leidschendam.

[3] Mutegi, J.K., Mugendi, D.N., Verchot, L.V. and Kungu, J.B. (2007) Impacts of vegetative contour hedges on soil inorganic-N cycling and erosional losses in Arable Steeplands of the Central Highlands of Kenya. In: Bationo, A., Waswa, B.S., Kihara, J., Kimetu, J., Eds. Advances in Integrated Soil Fertility Management in Sub-Saharan Africa: Challenges and Opportunities. Springer, Dordrecht, 679-689.

[4] Gitari, J.N., Kanampiu, F.K. and Matiri, F.M. (1996) Maize yield gap analysis for mid altitude areas of Eastern and Central Kenya regions. Proceedings of the 5th KARI Scientific Conference, Nairobi, October 1996, 215-225.

[5] Hassan, R.M., Murithi, F.M. and Kamau, G. (1998) Determinants of fertilizer use and the gap between farmers maize yield and the potential yields in Kenya. CAB International, Wallingford, 137-161.

[6] Shepherd, K.D. and Soule, M.J. (1998) Soil fertility management in Western Kenya: Dynamic simulation of productivity, profitability and sustainability at different resource endowment levels. Agriculture, Ecosystem and Environment, 71, 131-146. doi:10.1016/S0167-8809(98)00136-4

[7] Niang, A., De Wolf, J., Hansen, T., Nyasimi, M., Rommelse, R. and Mwendwa, K. (1998) Soil fertility replenishment and recapitalization project in Western Kenya. 
Progress report, Maseno.

[8] Adiel, R.K. (2004) Assessment of on-farm adoption potential of nutrient management strategies in Chuka Division, Meru South District, Kenya. Msc Thesis, Kenyatta University, Nairobi.

[9] Mugendi, D.N., Nair, P.K.R., Mugwe, J.N., O' Neill, M.K. and Woomer, P.L. (1999) Calliandra and Leucaena alley cropped with maize Part I. Soil fertility changes and maize production in the sub humid highlands of Kenya. Agroforestry Systems, 46, 39-50. doi:10.1023/A:1006288301044

[10] Donovan, G. and Casey (1998) Soil fertility management in sub-Saharan Africa. Technical Paper, World Bank, Washington DC, 408.

[11] Palm, C.A., Myers, R.J. and Nandwa, S.M. (1997) Organic-inorganic nutrient interaction in soil fertility replenishment. In: Buresh, R.J., Sanchez, P.A. and Calhoun F., Eds., Replenishing Soil Fertility in Africa, Soil Science Society of America, Madison, 193-218.

[12] Kimani, S.K. and Lekasi, J.K. (2004) Managing manures throughout their production cycle enhances their usefulness as fertilizers: A review. In: Batiano, A., Ed., Managing Nutrient Cycles to Sustain Soil Fertility in Sub-Saharan Africa, Academy of Science Publishers, Nairobi.

[13] Kenya Agricultural Research Institute (1994) Fertilizer use recommendations. Vol. 1-22. Fertilizer use recommendation project. KARI, Nairobi.

[14] Vanlauwe, B., Diels, J., Aihou, K., Iwuafor, E.N., Lyasse, O., Sanginga, N. and Merckx, R. (2002) Direct interactions between $\mathrm{N}$ fertilizer and organic matter: Evidence from trials with $15 \mathrm{~N}$-labeled fertilizer. In: Vanlauwe, B., Diels, J., Sanginga, N. and Merckx, R. Eds., Integrated Plant Nutrient Management in Sub-Saharan Africa: From Concepts to Practice, CAB International, Wallingford.

[15] Myers, R.J.K., Palm, C.A., Cuevas, E., Gunatilleke, I.U. N. and Brossard, M. (1994) The synchronization of nutrient mineralization and plant nutrient demand. In: Woomer P.L. and Swift, M.J. Eds., The Biological Management of Soil Fertility, John Wiley and Sons, Chichester.

[16] Jama, B.A., Swinkles, R.A. and Buresh, R.J. (1997) Agronomic and economic evaluation of organic and inorganic sources of Phosphorus in Westerbn Kenya. Agroforestry Journal, 89, 597-604.

[17] Chesson, A. (1997) Plants degradation by ruminants: Parallels with litter decomposition in soils. In: Cadisch, G. and Giller, K. Eds., Driven by Nature: Plant Litter Quality and Decomposition, CAB International, Wallingford, 47-66.

[18] Palm, C.A. and Rowland, A.P. (1997) Chemical characterization of plant quality for decomposition. In: Cadisch, G. and Giller, K.E. Eds., Driven by Nature: Plant Litter Quality and Decomposition, CAB International, Wallingford.

[19] Ayuke, F.O., Rao, M.R., Swift, M.J. and Opondo-Mbai, M.L. (2004) Effect of organic and inorganic nutrient sources in soil mineral $\mathrm{N}$ and maize yields in Western Kenya. In: Bationo, A. Ed., Managing Nutrient Cycles to
Sustain Soil Fertility in Sub-Saharan Africa, CIAT, Cali.

[20] Wallace, J.S. (1996) The water balance of mixed treecrop systems. In: Ong, C.K. and Huxley, P. Eds., Tree Crops Interactions, a Physiological Approach, CAB International, Wallingford, 73-158.

[21] Mutuo, P.K., Mukalama, J.P. and Agunda, J. (2000) Onfarm testing of organic and inorganic phosphorus sources on maize in Western Kenya. TSBF Report, Cali, 22.

[22] Mugendi, D. N., Mucheru-Muna, M., Mugwe, J., Kung'u, J.B. and Batiano, A. (2007) Improving food production using "best bet" soil fertility technologies in the central highlands of Kenya. In: Batiano, A., Waswa, B., Kihara, J. and Kimetu, J., Eds., Advances in Integrated Soil Fertility Management in Sub-Saharan Africa, Challenges and Opportunities, Springer, Berlin. doi:10.1007/978-1-4020-5760-1_31

[23] Mucheru, M., Mugendi D.N., Kung'u, J.B., Mugwe, J. and Bationo, A. (2007) Effects of organic and mineral fertilizer inputs on maize yield and soil chemical properties in a maize cropping system in Meru South District, Kenya. Agroforestry Systems, 69, 189-197. doi:10.1007/s10457-006-9027-4

[24] Kapkiyai, J.J., Karanja, N.K., Woomer, P.L and Qureshi, J.N. (1998) Soil organic carbon fractions in a long term experiment and the potential for their use as a diagnostic assays in highland farming's of central Kenya. African Crop Science Journal, 6, 19-28.

[25] Vanlauwe, B., Diels, J., Aihou, K., Iwuafor, E.N., Lyasse, O., Sanginga, N. and Merckx, R. (2002) Direct interactions between $\mathrm{N}$ fertilizer and organic matter: Evidence from trials with $15 \mathrm{~N}$-labeled fertilizer. In: Vanlauwe, B., Diels, J., Sanginga, N. and Merckx, R., Eds., Integrated plant Nutrient Management in Sub-Saharan Africa: From Concepts to Practice, CAB International, Wallingford.

[26] Asghar, M. and Kanehiro, Y. (1980) Effects of sugarcane trash and pineapple residue on soil $\mathrm{pH}$, redox potential, extractable Al, Fe and Mn. Tropical Agriculture, 57, 245 258.

[27] Hue, N.V. (1992) Correcting soil acidity of a highly weathered ultisol with chicken manure and sewage sludge. Communications in Soil Science and Plant Analysis, 23, 241-264. doi:10.1080/00103629209368586

[28] Bayu, W., Rethman, N.F.G. and Hammes, P.S. (2005) The role of manure in sustainable soil fertility management in sub-Saharan Africa. Journal of Sustainable Agriculture, 25, 113-136. doi:10.1300/J064v25n02 09

[29] Mugendi, D.N., Monicah-Munah, Pypers, P., Mugwe, J., Kungu, J., Vanlauwe, B. and Merckx, R. (2010) Maize productivity as influenced by organic inputs and mineral fertilizers in a Nitisol soil in Meru South District. 19th World Congress of Soil Science, Soil Solutions for a Changing World, 1-6 August 2010, Brisbane.

[30] O’Hallorans J., Muñoz, M.A. and Marquez, P.E. (1997) Chicken manure as an amendment to correct soil acidity and fertility. Journal of Agriculture of the University of Puerto Rico, 81, 1-8.

[31] Haynes, R.J. and Ms. Mokolobate (2001) Ameriolation of aluminium toxicity and $\mathrm{P}$ deficiency in acid soils by 
addi- tion of organic residue. A critical review of the phenomenon and the mechanism involved. Nutrient Cycling in Agroecosystems, 59, 47-63.

doi:10.1023/A:1009823600950

[32] Nziguheba, G., Palm, C.A., Buresh, R.J. and Smithson, P. (1998) Soil phosphorus fractions and adsorption as affected by organic and inorganic sources. Plant and Soil, 198, 159-168. doi:10.1023/A:1004389704235

[33] Eghball, B. (2002) Soil properties as influenced by phosphorous and Nitrogen based manure and compost applications. Agronomy Journal, 94, 128-135. doi:10.2134/agronj2002.0128

[34] Mucheru, M.W. (2003) Soil fertility technologies for increased food production in Chuka, Meru South District, Kenya. M. Env.S Thesis, Kenyatta University, Nairobi.

[35] Kimetu, J.M., Mugendi, D.N., Palm, C.A., Mutuo, P.K.,
Gachengo, C.N., Nandwa, S. and Kungu, J.B. (2004) Nitrogen fertilizer equivalency values for different organic materials based on maize performance at Kabete, Kenya. Academy of Science Publishers, Nairobi.

[36] Mucheru, M., Mugendi, D.N., Micheni, A., Mugwe, J., Kung'u J., Otor, S. and Gitari, J. (2004) Improved food production by use of soil fertility amendment strategies in the Central Highlands of Kenya. In: Batiano, A., Ed., Managing Nutrient Cycles to Sustain Soil Fertility in SubSaharan Africa, Academy Science Publishers (ASP), in association with the Tropical Soil Biology and Fertility Institute of CIAT, Nairobi.

[37] Jama, B., Palm, C.A., Buresh, R.J., Niang, A.L., Gachengo, C., Nziguheba, G. and Amadalo, B. (2000) Tithonia as a green manure for soil fertility improvement in Western Kenya: A review. Agronomy Journal, 49, 201-221. doi:10.1023/A:1006339025728 